\title{
DYNAMICAL MODELING OF FREQUENCY CONTROLLED VARIABLE SPEED PARALLEL MULTISTAGE CENTRIFUGAL PUMPS
}

This paper presents a development of a model of a set of multistage centrifugal electro pumps including two 4 stage stainless steel centrifugal pumps, each coupled to a $4 \mathrm{~kW}$ three-phase induction motor, connected to a hydraulic application running under two control strategies including constant speed and variable speed methods. Each pump provides $16 \mathrm{~m}^{3} / \mathrm{hr}$ flow rate and $58_{\text {mwater }}$ head at BEP (Best Efficiency Point). Dynamicity of the model causes variations in all operational parameters of pumping system in any variation on consuming flow rate. Each electro pump has been driven with a variable frequency drive utilizing frequency control method for adjusting the rotational speed under a PID control regarding to match of pumping system operational point with the consumption point to save the energy. $83 \%$ energy saving is achieved by model in variable speed control strategy comparing to constant speed control strategy. MATLAB/SIMULINK software using ode45 solver and variable step size simulates this model.

Table 1.

Symbols and abbreviations

\begin{tabular}{|c|l|c|l|}
\hline Symbol & \multicolumn{1}{|c|}{ Description } & Symbol & \multicolumn{1}{|c|}{ Description } \\
\hline$p$ & Header Pressure & $P$ & Electrical Power \\
\hline$v_{g}$ & Gas Side Specific Volume & $n_{p}$ & Motor Pole Quantity \\
\hline$v_{\text {liq }}$ & Liquid Side Specific Volume & $n$ & Speed of Rotation \\
\hline$\beta_{w}$ & Bulk Modulus of Water & $\omega_{e}$ & Electricity Network Frequency \\
\hline$Q_{P 1} \& Q_{P 2}$ & Pump Flow Rate & $V$ & Motor Terminal Voltage \\
\hline$Q_{c}$ & Consumption Flow rate & $f$ & Terminal Reference Frequency \\
\hline$p_{c}$ & Consumption Pressure & $N$ & Number of stator wiring loops \\
\hline$R_{c}$ & Consumption Resistance & $\varphi$ & Magnetic Flux \\
\hline C.V. & Check Valve & $I$ & Motor inertia \\
\hline
\end{tabular}

* Mechanical Engineering Faculty, Islamic Azad University, Tabriz Branch, Iran, Email: faridkhayatzade@gmail.com (Corresponding Author);gh_jafar@yahoo.com 


\section{Introduction}

Pumping systems are of most applied systems in all over the industrial processes and consume a high percent of energy. Pumps currently consume $10 \%$ of global electricity [14]. However, there are quick notes to reduce the amount of energy consumed with these systems. A fine-tuned PID controlled variable speed pumping system consumes lower energy than that for constant speed and so PID controllers are widely used in pumping systems. As a result, mathematical modeling of a system can show the behavior of all parameters in a system including measurable and hard to measure parameters. For example, rotor current of an induction motor, hydraulic torque of a pump and other parameters that are not measurable in experimental set up or at least it is not momently easy to measure. The aim of this paper is to develop a dynamic and real model of a pumping system with all equipment that practically used in pumping stations. Therefore, pumping stations have been modeled with their auxiliary equipment more accurate and real that results in precise determination of pumping systems operational parameters according to their applications. A pumping station including two multistage centrifugal vertical stainless steel pumps has been considered and different parameters like head, flow rate in mechanical section and consumed electrical energy and rotational speed with two control strategies have been discussed.

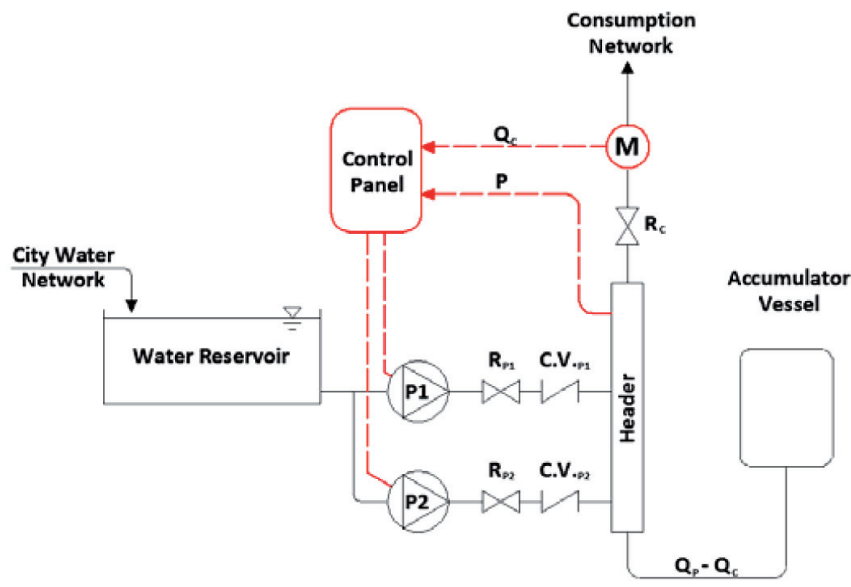

Fig. 1. Pumping station with two pumps

\section{Mathematical model}

The model has been set up on equipment shown in Fig. 1. In mechanical section, it includes a water reservoir, two parallel multistage centrifugal pumps, two headers in suction and pressure sides of pumps and an accumula- 
tor vessel connected to pressure side header of system. Electrical section of system contains a control panel with two control strategies. Figure 2 shows the models with constant and variable speed control strategies. It consists of a three-phase electricity source, a control panel, two electro pumps and a consumption network. Electricity source is a three-phase constant frequency provider, which supplies required electrical energy to three-phase induction motor crossing through controlling unit. The controller unit can be only a three-phase switch in constant speed control strategy or three-phase variable speed drive in variable speed control strategy. The centrifugal pump and consumption network models are the same in both strategies. The number of electro pumps in parallel connection depends on consumption network and the required pres-

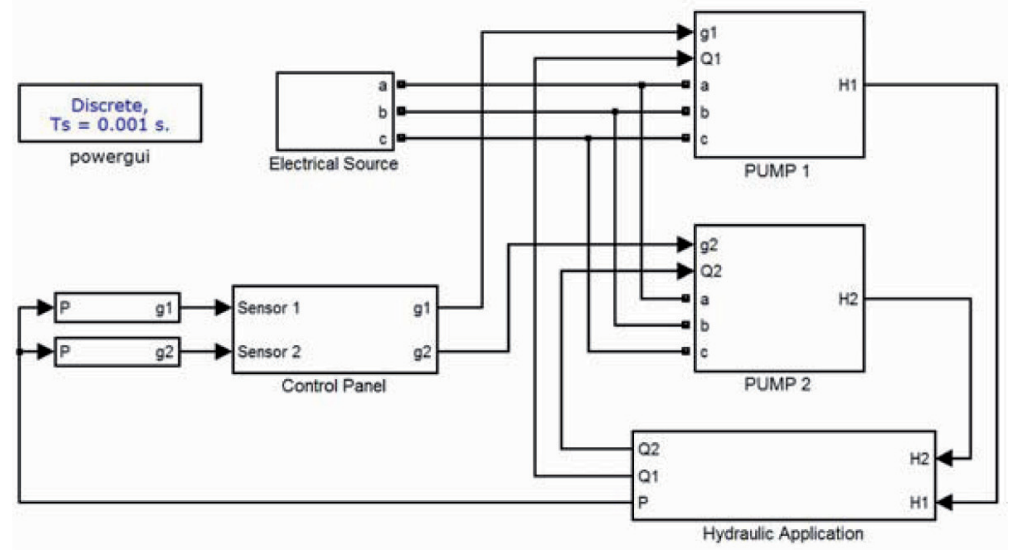

a) Constant speed control strategy

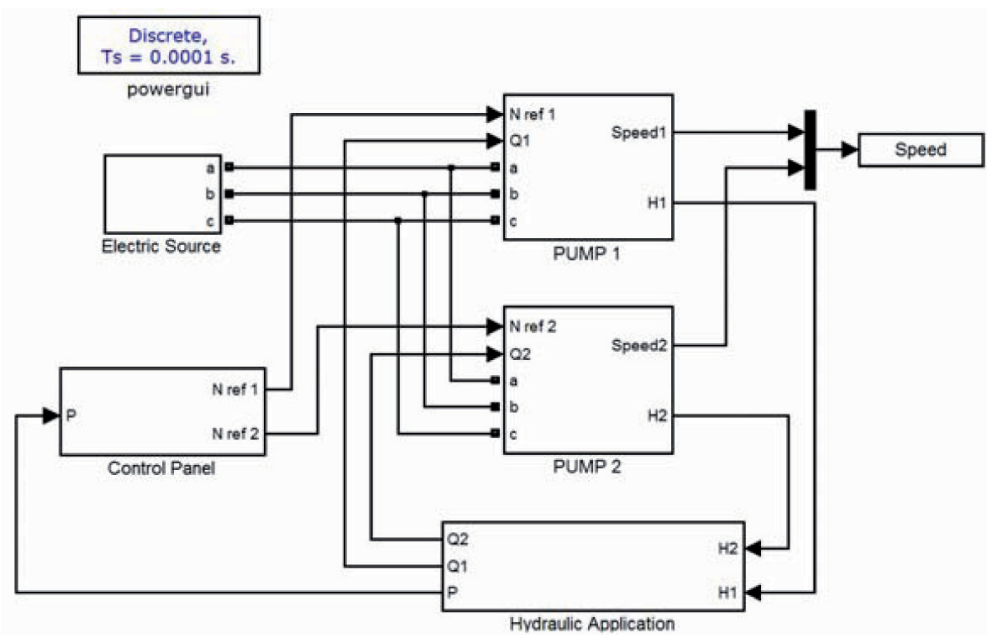

b) Variable speed control strategy

Fig. 2. Pumping station models 
sure. The pressure sensor connected to the header acts as a feedback signal provider for controlling system. It can be only a pressure-triggered switch for constant speed control strategy or a piezoelectric pressure sensor that converts the pressure to 4-20 mA analog current signal for variable speed controlling strategy. In variable speed strategy, PID controller determines reference speed for variable speed drive using feedback sensor. Therefore, variable speed drive varies the frequency of three-phase voltage supplied to induction motor. In this paper, variable voltage variable frequency method has been used for variable speed drive modeling with PID speed controller. Sub-models of general model have been mentioned in the following.

\subsection{Centrifugal pump model}

Centrifugal pump model described by Eq. (1) presents a model based on motor dynamics. The equation is a form of Riccatti equation and $a, b$ and $c$ are determinable constants from pump geometry.

$$
H=a Q^{2}+b Q n+c n^{2}
$$

This equation shows the influence of flow rate and speed on produced pressure with centrifugal pump; also, it can match with steady - state conditions of pressure versus flow rate curve of centrifugal pump. Eq. (2), results in equality of hydraulic and mechanical power of pump.

$$
T_{p}=d Q^{2}+e Q n+f n^{2}
$$

Frictional torque as a function of friction coefficient and rotational speed is added to pump torque and formed load torque of pump as mentioned in Eq. (3).

$$
T_{L}=T_{P}+T_{\text {friction }}=T_{P}+B n
$$

Eqs. (1)-(3) together, form the centrifugal pump model that flow rate from consumption network and speed from induction motor are its inputs and head to consumption network and load torque to motor are its outputs. [1]

\subsection{Consumption network model}

This part of model applies various consumption scenarios to the model. In addition, it determines the number of pumps connected in parallel together for supplying the consumption flow rate. As shown in Fig. 1, the consumption net- 
work includes an accumulator vessel, a header and resistances of the pump and consumer which different consumption patterns that could be defined for the system using time dependent functions for consumer resistance. The header pressure is measured by a sensor as a criterion and transmitted to PID controller. Eqs. (4)-(5) calculate the pump and the consumer resistances.

$$
\begin{gathered}
R_{p}=\frac{\sqrt{\rho g H-p}}{Q_{p}} \\
R_{c}=\frac{\sqrt{p-p_{c}}}{Q_{c}}
\end{gathered}
$$

An air-water accumulator vessel is made of a metal rigid body and elastic balloon connected to the header for absorbing pressure fluctuations, reducing of hydraulic impacts of the pump start and stop times, and finally reducing the pump working time in order to save energy through compensating small pressure drops of the header when it is fully charged. Using bulk modulus stated in Eq. (6) in which the flow rate is the difference of the pump and the consumption flow rates denoted in Eq. (7), pressure of accumulator vessel is calculated. Note that the pump flow rate in this situation is the sum of two pumps flow rates.

$$
\begin{gathered}
\dot{p}_{a c c}=\frac{\beta_{w}}{v_{a c c}}\left(Q_{a c c}-\dot{v}_{a c c}\right) \\
Q_{a c c}=Q_{P}-Q_{c}=\left(Q_{P 1}+Q_{P 2}\right)-Q_{c}
\end{gathered}
$$

The two main equations used to analyze the gas characteristics are the ideal gas law and the polytropic process equations formulated in Eq. (8), Eq. (9). For gas accumulators, an isentropic polytropic process is usually assumed and $\mathrm{n}$ is one for an isentropic process. For exact analysis of accumulator vessel, three processes including pre-charge, charge and discharge processes considered.

$$
\begin{gathered}
p v=n R T \\
p_{g} v_{g}^{K}=\text { Constant }
\end{gathered}
$$

Differentiating Eq. (9) leads to Eq. (10).

$$
\dot{p}_{g} v_{g}^{K}+K p_{g} \dot{v}_{g} v_{g}^{K-1}=0
$$


Eq. (11) states mass conservation inside accumulator.

$$
\dot{p}_{l i q}=-\dot{p}_{g}
$$

Eq. (12) results in substituting of Eq. (10) and Eq. (11) in Eq. (6).

$$
\dot{p}=\frac{\beta}{v_{\text {liq }}} \frac{Q_{P}-Q_{c}}{\left[1+\frac{\beta}{K p}\left(\frac{v_{g}}{v_{l i q}}\right)\right]}
$$

\subsection{Header model}

The header is located between the pumps and the consumer that the pumps feed with flow rate in related pressure, and the consumer picks up flow rate in consumption pressure from it. Pressure of the header is the determinative factor for deciding about running strategy of the pumps. Header pressure or water side pressure of accumulator is equal to the gas side pressure and may be calculated through integrating of pressure variations of accumulator vessel that will be extracted in the following section.

$$
p=\int_{0}^{p} \dot{p} d t
$$

\subsection{Induction MotorModel}

Extracted load torque from equation Eq. (3) applied to motor shaft through coupling of rotor and pump's shaft. Eq. (14) states Newton's second law for the coupling. The characteristic curve of the induction motor is shown in Fig. 3.

$$
T_{e}-T_{L}=I \frac{\pi}{30} \frac{d n}{d t}
$$

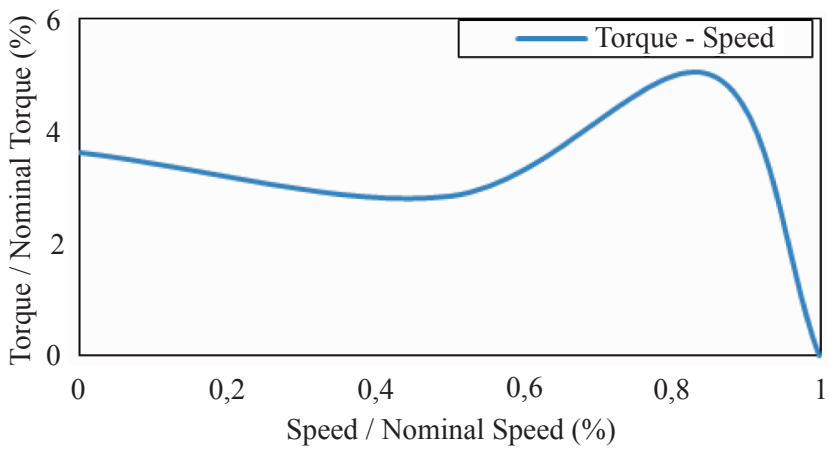

Fig. 3. Squirrel cage characteristic curve 


\subsection{Speed control strategy}

\subsubsection{Constant speed control strategy}

Constant speed strategy prescribes the pump to run if the pressure drops under the adjusted set point utilizing a pressure switch connected to the header. Therefore, in any pressure drop below the mentioned point, this strategy applies three-phase voltage with nominal frequency of $\omega_{e}$ to the induction motor stator, so the electro pump runs at its nominal speed. The cheaper price is the first and the biggest reason for applying this strategy in some pumping systems. Eq. (15) determines the rotational speed in nominal frequency.

$$
n=\frac{120 \omega_{e}}{n_{P}}
$$

\subsubsection{Variable speed control strategy}

At this strategy, the three-phase voltage applied to induction motor crossing a three-phase VFD (Variable Frequency Drive). The variable frequency drive changes the $\mathrm{AC}$ sinusoidal voltage into $\mathrm{DC}$ voltage by passing through a rectifier. Then the controlled voltage with controlled frequency is applied to IGBT (Insulated Gate Bipolar Transistor) units. The switching frequency and the arrangement are determined by SPWM (Sinusoidal Pulse-Width Modulation). There are several methods for determining of the switching frequency of IGBTs. The frequency control method is based on stability of electromagnetic flux. Therefore, Eq. (16) states the stability of voltage-frequency ratio. [8]

$$
\frac{V}{f}=4.44 N \varphi_{\max }
$$

Figure $4 \mathrm{a}$ shows the model of variable frequency drive with frequency control in variable speed control strategy where three-phase voltages with nominal constant frequency is the input power of drive and three-phase voltage with variable frequency is the output of drive. The reference speed from PID controller is the speed on which the drive should adjust the pump rotational speed. Figure $4 \mathrm{~b}$ shows the variations of voltage in reference to nominal voltage ratio versus frequency. At low frequencies, declaration in stator impedance decreases gap flux, so the constant ratio increased slightly. Inside SPWM, according to Eq. (16), for the voltage amplitude and PID output speed for the frequency, there are made the three-phase voltages. So the three-phase voltage made with frequency control compares with a triangular signal. Only, 
if the voltage amplitude is larger than the triangular signal amplitude, the output signal to the corresponding IGBT is equal to one. Therefore, SPWM produces the frequency-controlled switching pulses of the IGBTs. [6]
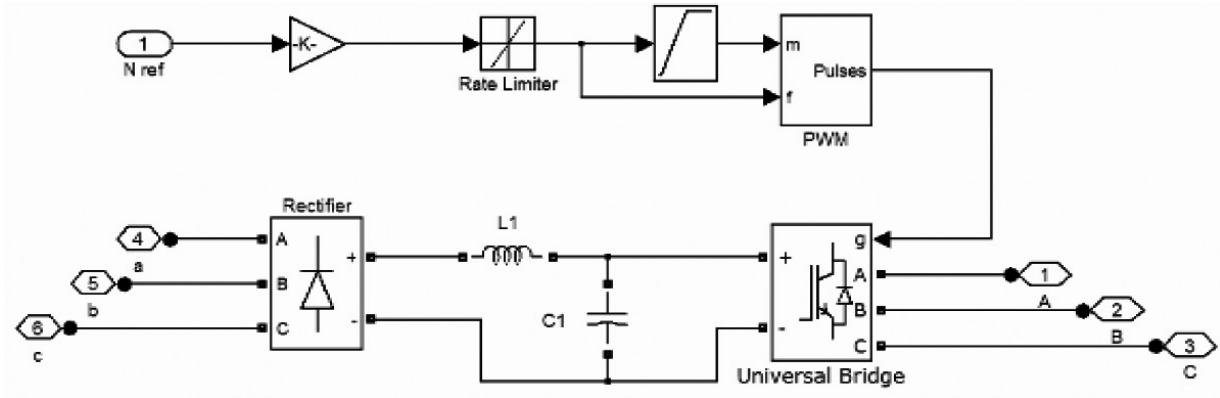

a) VFD Model

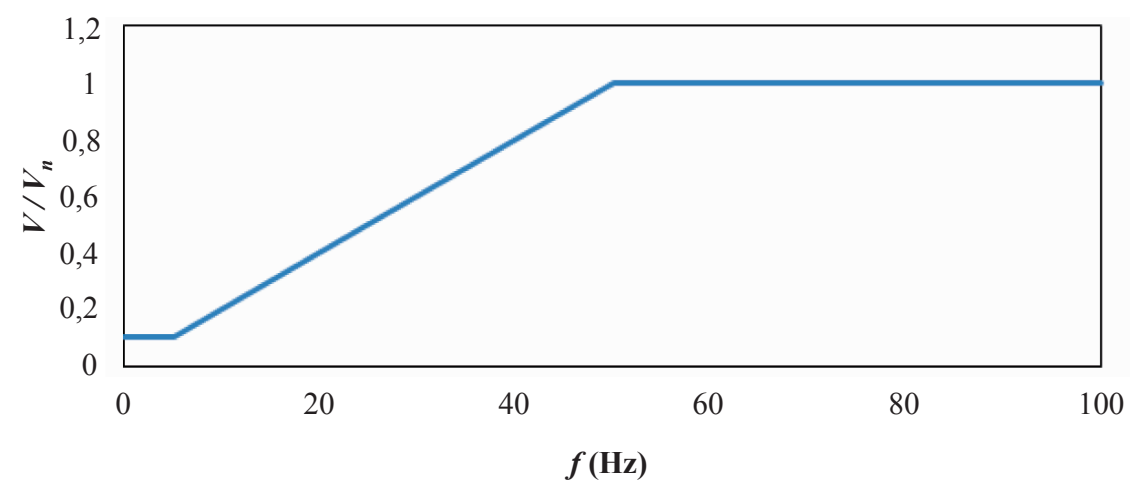

b) $V / f=c t e$

Fig. 4. Three-phase VFD

\subsubsection{PID controller of rotational speed model}

As a feedback of the system, speed equivalent of the header pressure is reported continuously to the PID controller. Output speed of PID controller is the reference speed for VFD.

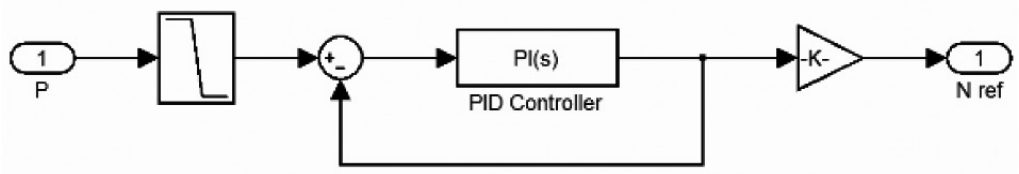

Fig. 5. PID controller of speed 


\subsection{Pressure sensor model}

The pressure sensor is only pressure-triggered switch adjusted to a desired pressure level at constant speed control strategy where it is an analog pressure transducer, which transmits pressure to PID control in variable speed control strategy.

\subsection{Control Panel}

The control panel exists in both control strategies and decides for run or stop of centrifugal pumps. However, the signal of a flow meter connected to the consumption network entrance is the best parameter for metering and deciding about the number of running pumps; because of economic reasons, a pressure sensor connected to output header provides an acceptable signal as a feedback for the control panel.

\section{Results}

The modeled pumping station includes two vertical stainless steel multistage centrifugal pumps with 4 stages, coupled with a three-phase $4 \mathrm{~kW}$, $50 \mathrm{~Hz}, 380 \mathrm{~V}$ AC nominal voltage, 2 poles and $2900 \mathrm{RPM}$ nominal speed squirrel cage induction motor. An accumulator vessel with 100-liter capacity connected to a header assuming $80 \%$ gas and $20 \%$ water content at first. The modeled pressure sensor is a 0-10 Bar ranged pressure switch in constant speed control strategy and an analog piezoelectric pressure transmitter with $24 \mathrm{~V}$ DC feed voltage and 4-20 mA output current in variable speed control strategy. The applied nominal voltage is $50 \mathrm{~Hz}, 380 \mathrm{~V} \mathrm{AC}$ for both strategies. The variable frequency drive is a three-phase $4 \mathrm{~kW}$ converter for each electro pump. $V / f=$ cte method used for obtaining SPWM pulses for IGBTs. Constant coefficients of the head model for each pump were obtained as in Eq. (17).

Primary conditions and constant parameters are listed in table 2. Simulation has been done in MATLAB/SIMULINK 7.9.0 (R2009b) software with ode 45 solver and variable time step size with discrete simulation type and $100 \mathrm{e}-6$ sampling time. The modeled pumps and other parts of the model are the same as those of the mentioned building domestic water pumping station equipment. In addition, head and flow rate of the system have been obtained from pressure sensor and flow meter connected to output of pumping station.

$$
H=(-1 e-6) Q^{2}+(4.91) Q n+(75 e-5) n^{2}
$$


Table 2 .

Constant characteristics of modeling

\begin{tabular}{|l|c|c|c|}
\hline \multicolumn{1}{|c|}{ Symbol } & Description & Symbol & Description \\
\hline Head $(\mathrm{m})$ & $68-32$ & Nominal RPM & 2900 \\
\hline Flow Rate $\left(\mathrm{m}^{3} / \mathrm{hr}\right)$ & $10-24$ & Network Frequency $(\mathrm{Hz})$ & 50 \\
\hline Number of Stages & 4 & Rotor Type & Squirrel Cage \\
\hline Nominal Power $(\mathrm{kw})$ & 4 & $\mathrm{n}_{\mathrm{p}}$ & 2 \\
\hline Voltage $(\mathrm{V})$ & 380 & $\mathrm{~J}\left(\mathrm{~kg} \cdot \mathrm{m}^{2}\right)$ & 0.093 \\
\hline
\end{tabular}

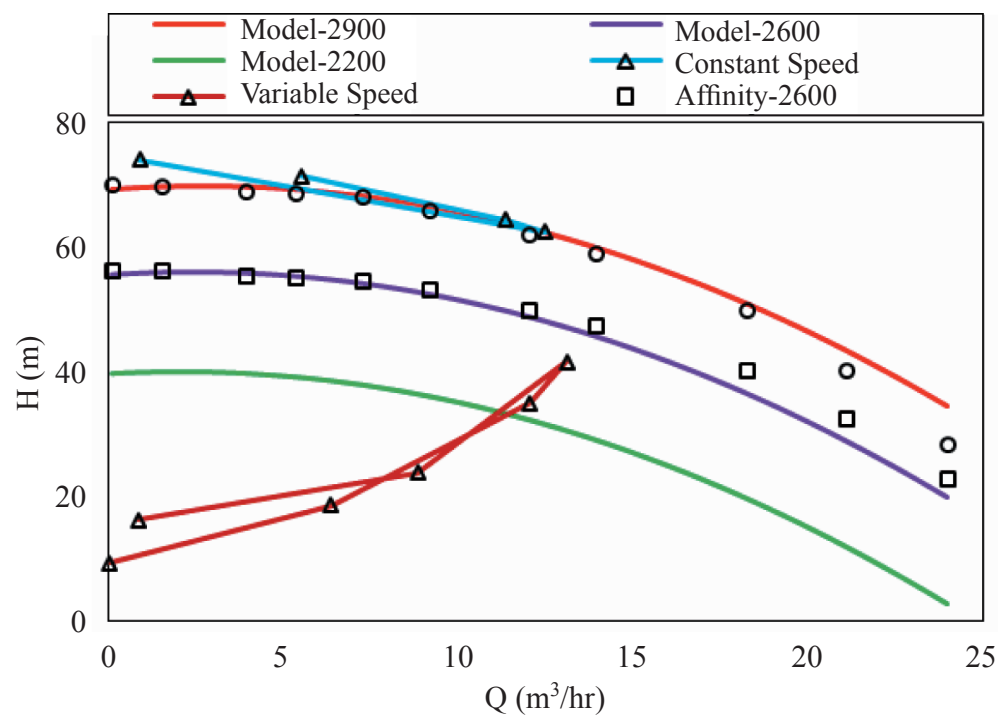

Fig. 6. Multistage centrifugal pump model test, Head versus Flow rate curve [15]

According to Fig. 6, the head model for each pump matches with experimental data and affinity results. Some of transient operational points of both control strategies also have been shown in Fig. 6. According to Fig. 6, it could be predicted from area under operational points of constant speed control strategy that this area is larger than that for variable speed, which results in more energy consumption by constant speed control strategy. It has been discussed in detail in Fig. 10. All sub-models have been tested separately and behavior of all is reliable. Simulation run time is 120 seconds and any favorite consumption scenario could be applied to model. This paper uses a scenario that simulates fulfilling of the system in first 15 seconds, consumption during 75 seconds and then minimizing of consumption in next 30 seconds. This applies to maximum and minimum demands for water, and allows us to discuss about the behavior of each parameter. Figure 7 shows the variations of flow 
rate in both control strategies. Perfect tracing of a given scenario is pointed out in both strategies. In Fig. 8, the pressure of header and also of each of pumps are mentioned. Also, the pumps are working at the point that produces higher pressure to handle the consumption. Because of high demand for water consumption, the header pressure is rather low.

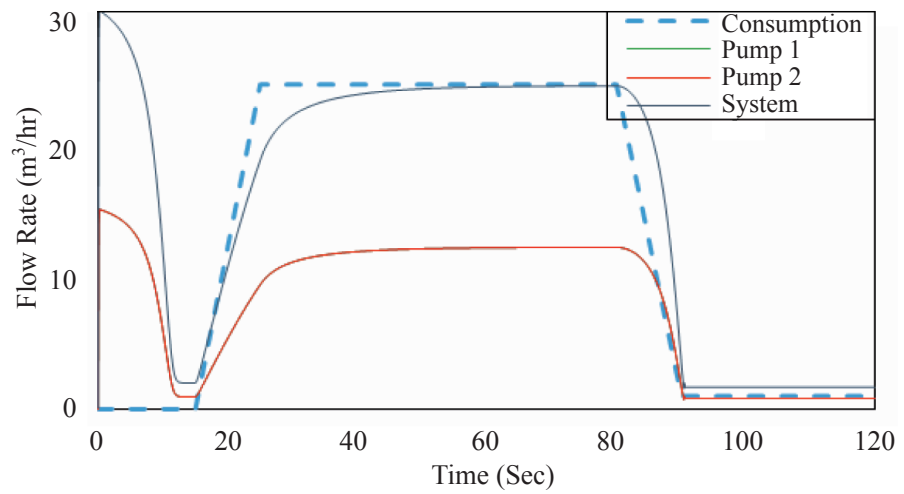

a) Constant speed strategy

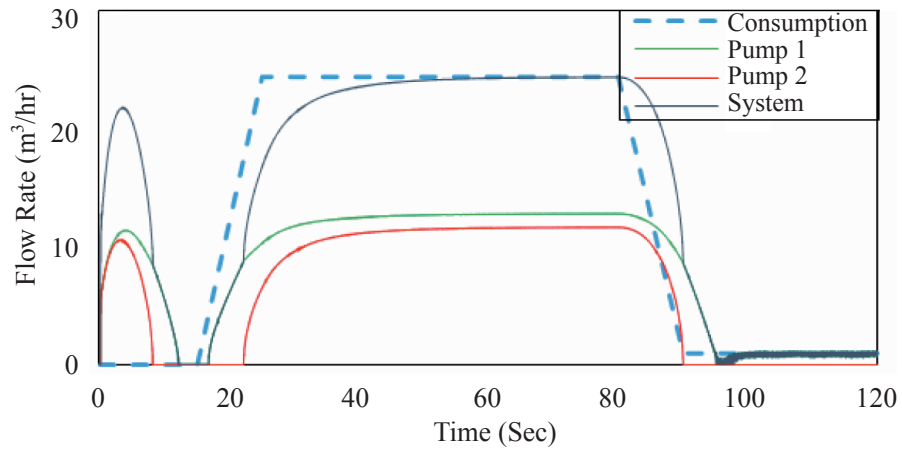

b) Variable speed strategy

Fig. 7. Flow rates

Both Fig. 7 and Fig. 8 show transient operational points of each pump. Regarding to Fig. 7 and Fig. 8, the empty accumulator vessel is charged in first 12 seconds and this is why the flow rate of the system is rather high at the first. the same step in constant speed strategy includes a rapid increase in flow rate immediately after pumps run that causes a hydraulic shock exposing to consumption network. The rapid increase in rotational speed in constant speed strategy is the main cause for this shock and it will expose to consumption network in each time that the pump should run. In same step, there is an increment in flow rate without any hydraulic shock in variable speed strategy. So, this advantage of variable speed control strategy makes it 


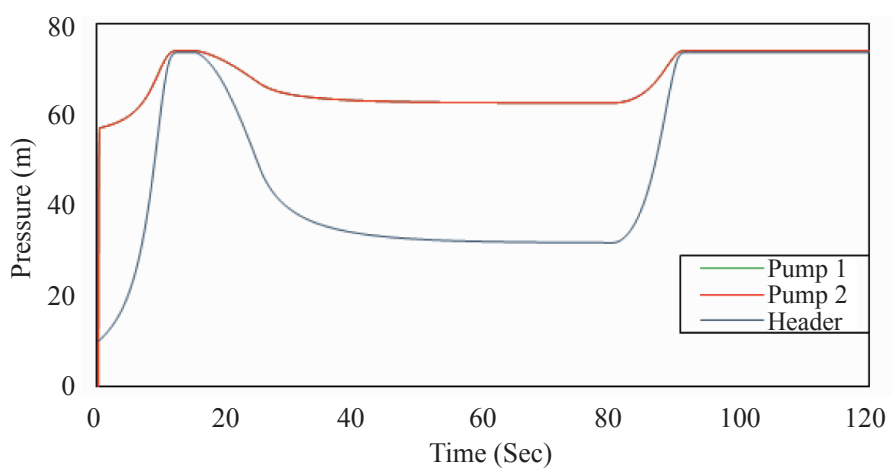

a) Constant speed strategy

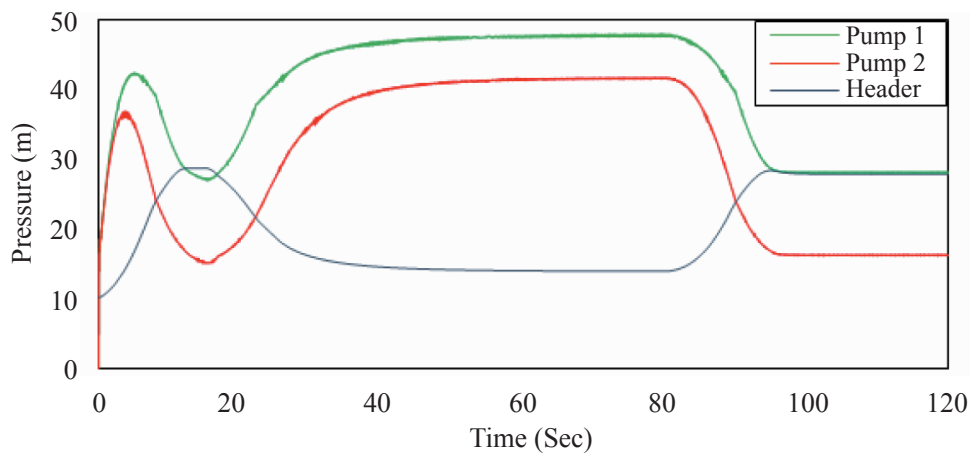

b) Variable speed strategy

Fig. 8. Header pressure

a suitable choice for utilizing in domestic water pumping station of residential, commercial and similar applications. Figure 9 shows rotational speeds of both strategies. In Fig. 9a there is an immediate rise in electro pump speed from zero to the nominal speed in 0.3 second and this is the main reason for hydraulic shock discussed in previous paragraph. In Fig. 9b, PID reference for drive shown with dashed line makes the drive to trace it and the drive makes the electro pump run with drive reference speed for electro pump. Parameters $\mathrm{P}, \mathrm{I}$ and D in PID speed controller have been set to 1, 0.9 and zero. Matching between these three parameters is very important as it makes the electro pump speed controllable. Note that, because of low header pressure at the start, both pumps run and act like each other, and this cause an overlap in flow rate of head and speed curves in constant speed control strategy. One of the main purposes of this paper is to show the energy saving amount of variable speed strategy in comparison with constant speed strategy as shown in Fig. 10. 


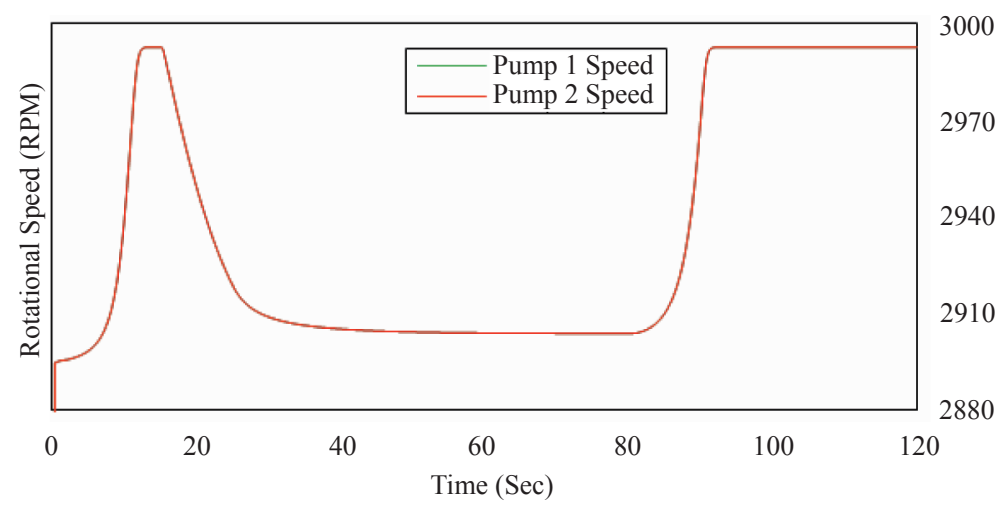

a) Constant speed strategy

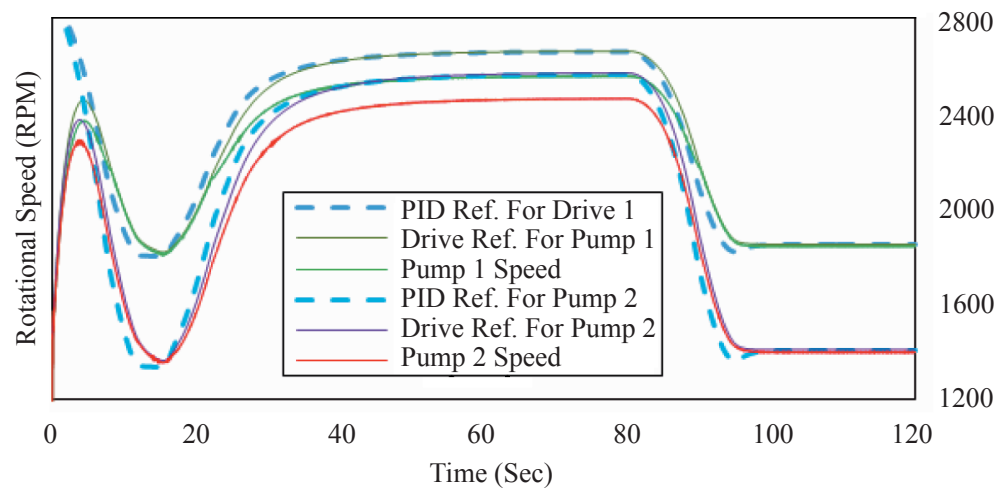

b) Variable speed strategy

Fig. 9. Electro pumps speeds

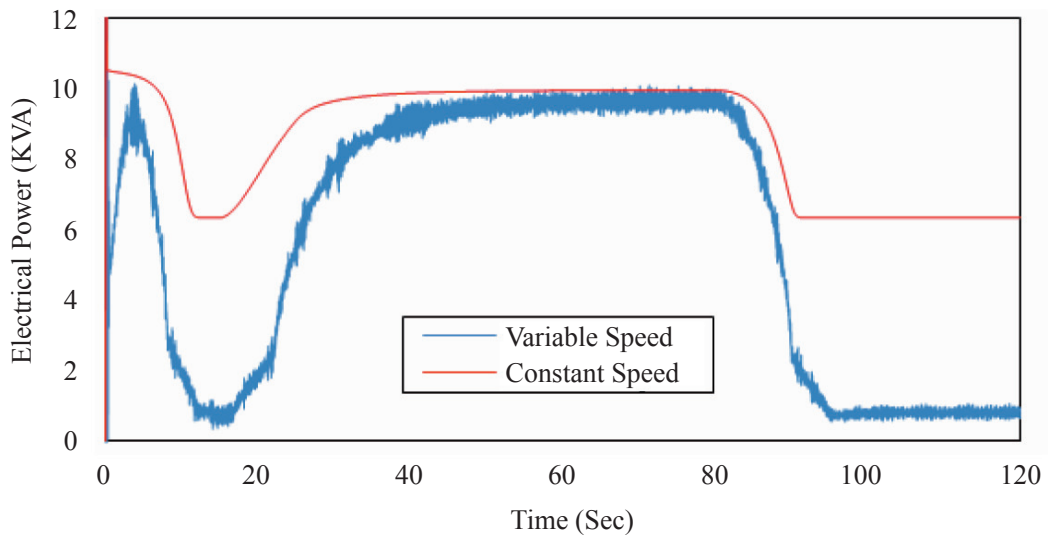

Fig. 10. Electrical Power 


\section{Conclusion}

The consumed electrical power in each step of a given scenario is listed in table 3, and both control strategies are compared. According to table 3 , at the first 10 seconds, there is an increment in power for charging of empty expansion vessel. In next 10 seconds there is a significant energy saving using variable speed strategy because of declaration in demand. After this step, until second 80th, because of water demand increase, the variable speed strategy behaves like constant speed one, but even in maximum demand it consumes lower power than the constant speed strategy. In next steps, the variable speed strategy perfectly shows its advantages to constant speed strategy, because it consumes 83 percent lower than constant speed strategy. In most residential, commercial and similar applications, the need for huge amount of water that needs a maximum flow rate has occurred only in $5 \%$ of the operation time, and the remaining $95 \%$ needs only a little amount of $\mathrm{flow}$. This is only one of advantages that utilizing of variable speed strategy brings and makes it a suitable choice to meet domestic water demand of buildings. Indeed, the variable speed control strategy matches the application consumption point with working point of pumping station and so it consumes only the needed amount of energy. For example, there is no need for $70 \mathrm{~m}$ pressure in the header, but the constant speed control strategy makes this pressure such high.

Table 3.

Consumed electrical power

\begin{tabular}{|l|c|c|c|c|c|c|}
\hline \multicolumn{1}{|c|}{ Time (Sec) } & $0-10$ & $10-20$ & $20-40$ & $40-80$ & $80-90$ & $90-120$ \\
\hline Constant speed (KVA) & 10.01 & 6.71 & 9.40 & 9.97 & 9.12 & 6.36 \\
\hline Variable speed (KVA) & 6.04 & 1.24 & 6.57 & 9.11 & 7.31 & 1.08 \\
\hline Energy saving & $40 \%$ & $82 \%$ & $30 \%$ & $9 \%$ & $20 \%$ & $83 \%$ \\
\hline
\end{tabular}

Manuscript received by Editorial Board, October 25, 2013;

final version, June 01, 2015

\section{REFERENCES}

[1] Skovmose Kallesøe C.: Fault Detection and Isolation in Centrifugal Pumps. PhD Thesis, Aalborg University, 2005.

[2] K.L.Shi, T.F.Chan, Y.K.Wong and S.L.Ho: Modeling and simulation of three phase induction motor using Simulink. Department of Electrical Engineering, Hong Kong Polytechnic University, 1999.

[3] Krause, P.C.: Simulation of symmetrical induction machinery. IEEE Trans. Power Apparatus Systems, 1965.

[4] Rashid M. H. (Ed.): Power Electronics Handbook, Devices, Circuits and Applications. Second Edition, Florida, USA.

[5] Fang Lin Luo, Hong Ye, Rashid M. H.: Digital Power Electronics and applications.

[6] Ion Boldea, S.A. Nasar: Electric Drives. eBook, 2005. 
[7] C. Thanga Raj, S. P. Srivastava, and Pramod Agarwal: Energy efficient control of three phase induction motor. International Journal of Computer and Electrical Engineering, 1793-8198, April 2009.

[8] Ansari, D.M. Deshpande, 'Mathematical Model of Asynchronous Machine' International Journal of Engineering Science and Technology, Vol. 2(5), (2010).

[9] Rizwan Uddin: Steady state characteristics based model for centrifugal pump transient analysis. Department of Mechanical, Aerospace and Nuclear Engineering, University of Virginia, USA, 1994.

[10] Dr.ir. S.A. Miedema: Modeling and simulation of the dynamic behavior of a pump/pipeline system. Delft University of Technology, 2010.

[11] Chee-Mun Ong: Dynamic simulation of electric machinery using Matlab/Simulink. Prentice Hall, 1998.

[12] Karanay i I, M .F. Rahman and C. Grantham: A Complete Dynamic Model for a PWM VSI-fed rotor flux oriented vector controlled Induction Motor Drive using SIMULINK. University of New South Wales, Sydney, NSW 2052, Australia, 2009.

[13] Thanga Raj, Member IACSIT, S. P. Srivastava, and Pramod Agarwal: Energy Efficient Control of Three-Phase Induction Motor. International Journal of Computer and Electrical Engineering, April 2009.

[14] GRUNDFOS PUMPS, CR Series, Multistage Centrifugal Pumps, 2012.

[15] LOWARA PUMPS, SV Series, Multistage Centrifugal Pumps Catalog, 2011.

[16] Andrei Magyari: Study regarding the possibilities of improving the parameters of a petroleum products main pipe transport system. University of Petroşani, Romania, 2010.

[17] S. Leirens, C. Zamora, R.R. Negenborn, and B. De Schutter: Coordination in urban water supply networks using distributed model predictive control. Proceedings of the 2010 American Control Conference, Baltimore, Maryland, pp. 3957-3962, July, 2010.

[18] Kiselychnyk O., Bodson M., Werner H., 'Interactive Energy Saving Control of Water Supply Pump based on Pressure Measurement', Вісник КДПУ імені Михайла Остроградського. Випуск (2009).

[19] K. Grotenburg: Modeling and dynamic simulation of variable speed pump storage units incorporated into the German electric power system, 2001.

\section{Modelowanie dynamiczne wielostopniowych równoległych pomp odśrodkowych o zmiennej prędkości sterowanych częstotliwościowo}

\section{Streszczenie}

W artykule przedstawiono opracowanie modelu zespołu wielostopniowej elektrycznej pompy odśrodkowej składającego się z dwu czterostopniowych pomp ze stali nierdzewnej, z których każda jest napędzana trójfazowym silnikiem indukcyjnym o mocy $4 \mathrm{~kW}$ i połączona $\mathrm{z}$ odbiorczym urządzeniem hydraulicznym. W sterowaniu pompy stosuje się dwie strategie, metodę stałej i zmiennej prędkości. Każda z pomp zapewnia prędkość przepływu $16 \mathrm{~m}^{3} /$ godz i ciśnienie $58 \mathrm{~m}$ słupa wody w punkcie odpowiadającym najlepszej sprawności (BEP). Dynamika modelu powoduje, że wszystkie parametry robocze zmieniają się przy zmianie prędkości przepływu po stronie odbiorczej. Każda z elektro-pomp jest napędzana ze zmienną częstotliwością metodą sterowania częstotliwością w regulatorze typu PID, co zapewnia dostosowanie parametrów roboczych systemu pompy do konsumpcji wody i oszczędność energii. W modelu opartym na strategii sterowania ze zmienną prędkością osiągnięto $83 \%$ oszczędność energii w porównaniu ze strategią sterowania przy stałej prędkości. Symulację modelu wykonano przy pomocy oprogramowania MATLAB/SIMULINK z pakietem numerycznym ode45 stosując zmienną długość kroku. 
